\title{
Yeşile Boyama ve Yeşil Satın Alma Davranışı Arasındaki İlişkide Yeşil Marka İmajı ve Yeşil Marka Sadakatinin Aracılık Rolü

\author{
(The Mediating Role of Green Brand Image and Green Brand Loyalty in the Relationship \\ between Greenwash and Green Purchase Behavior)
}

\author{
Sinan ÇAVUŞOĞLU iD a \\ a Bingöl Üniversitesi, Sosyal Bilimler MYO, Yönetim ve Organizasyon, Bingöl, Türkiye. sinankys42@gmail.com
}

\section{MAKALE BİLGİİ ÖZET}

\section{Anahtar Kelimeler:}

Yeşile boyama

Yeşil marka imaj1

Yeşil marka sadakati

Yeşil satın alma davranışı

Gönderilme Tarihi 10 Mart 2021

Revizyon Tarihi 25 Ağustos 2021

Kabul Tarihi 30 Ağustos 2021

Makale Kategorisi: Araştırma Makalesi

Amaç - Çalışma, işletmeler tarafından gerçekleştirilen yeşile boyama faaliyetlerinin tüketicilerin yeşil satın alma davranışları üzerinde etkisini araştırmak amacıyla gerçekleştirilmiştir. Çalışmada ayrıca yeşil marka imajı ve yeşil marka sadakatinin yeşil satın alma davranışı üzerinde nasıl bir aracı etkiye sahip olduğu belirlenmeye çalışılmıştır.

Yöntem - Araştırmanın evrenini Türkiye'de yeşil ürünler satın alma deneyimi olan bireyler oluşturmaktadır. Yapısal ilişkiyi ortaya çıkarmak için anket tekniği kullanılmıştır. Online olarak gerçekleştirilen toplam 410 geçerli anket Smart PLS Professional 3.3.3 yazılımı kullanılarak analiz edilmiştir. Araştırmada ölçülmesi amaçlanan hipotezlerin testi için bootstrapping tekniği uygulanmıştır. Değişkenlere ait yapı, uyum ve ayrım geçerlikleri hesaplanmıştır. Son olarak yol analizi ile hipotezlerin doğruluğu test edilmiştir.

Bulgular - Elde edilen sonuçlara göre yeşile boyama, yeşil marka imajı, yeşil marka sadakati ve yeşil satın alma davranışını negatif yönde etkilemektedir. Elde edilen bulgular neticesinde yeşil marka imajı ve yeşil marka sadakati yeşil satın alma davranışını pozitif yönde etkilemektedir. Çalışma da ayrıca yeşile boyama faaliyetleri ile yeşil marka imajının ve yeşil marka sadakatinin yeşil satın alma davranışı üzerinde negatif yönde kısmi aracılık (rekabetçi) etkisi tespit edilmiştir.

Tartışma -. Pazardaki yeşil ürünlere olan güçlü ihtiyaç dünyayı değiştirmekte, bu nedenle işletmeler rekabet edebilmek için yeşil pazarlamayı benimsemeye isteklidirler. Literatür, yeşil ürünlerin çevresel iddialarının doğru ve şeffaf olması gerektiğini savunsa da, yeşile boyama pazarda hala etkin bir şekilde kullanılmaktadır. İşletmelerin yeşile boyama faaliyetlerini azaltarak, yeşil marka imajı ve yeşil marka sadakati aracılı̆̆gyla tüketicilerinin yeşil satın alma davranışını artırmak için kritik bir yaklaşım göstermesinin önemli olduğu söylenebilir.

ARTICLE INFO ABSTRACT

\section{Keywords:}

Greenwash Green brand image Green brand loyalty Green purchase behavior

Received 10 March 2021 Revised 25 August 2021 Accepted 30 August 2021

\section{Article Classification:} Research Article

\begin{abstract}
Purpose - The study was carried out to investigate the effect of greenwash activities carried out by businesses on the green purchasing behavior of consumers. The study also attempted to determine what kind of mediating effect green brand image and green brand loyalty have on green purchasing behavior.

Design\methodologylapproach - The universe of the research green products in Turkey are individuals who purchase experience. Questionnaire technique was used to reveal the structural relationship. A total of 410 valid questionnaires conducted online were analyzed using Smart PLS Professional 3.3.3 software. The bootstrapping technique was used for testing the hypotheses aimed to be measured in the study. The structure, consistency and discrimination validities of the variables were calculated. Finally, the accuracy of the hypotheses was tested with path analysis.

Findings - According to the results, greenwash, negatively affects green brand image, green brand loyalty and green purchasing behavior. As a result of the findings obtained, green brand image and green brand loyalty positively affect green purchasing behavior. The study also found a negative partial mediating (competitive) effect of greenwash activities and green brand image and green brand loyalty on green purchasing behavior.

Discussion - The strong need for green products in the market is changing the world, so businesses are willing to adopt green marketing to compete. Although the literature argues that the environmental claims of green products should be accurate and transparent, greenwash is still used effectively in the market. It can be said that it is important for businesses to take a critical approach to increase the green buying behavior of their consumers through green brand image and green brand loyalty by reducing their greenwash activities.
\end{abstract}




\section{GİRIŞ}

Yeşil pazarlama, çevreye duyarlı tüketicilerin dikkatini çekebilmek adına önemli bir araç haline gelmiştir. Son zamanlarda daha fazla işletme "yeşil", "eko", "çevre dostu", "sürdürülebilirlik" ve "dünya dostu" gibi reklam terimlerini oldukça sık kullanmaktadır (Chang, 2011; Parguel vd., 2011). Ancak bu terimlerin popüler hale gelmesi beraberinde çevresel niteliklerle ilgili pek çok yeşil iddiaları da belirsiz ve güvenilmez bir hale getirmiştir. Bu belirsizlik ve güvensizlikte "yeşile boyama" olarak nitelendirilen bir kavramı ortaya çıkartmıştır. Yeşile boyama, yeşil satın almalar için tüm pazarı tehlikeye atacak ve yeşil pazarı baltalayacak bir sonuca neden olmaktadır (Hamann ve Kapelus, 2004). İşletmeler pazarda yeşil imaj oluşturabilmek adına, ürün hakkında olumsuz bilgileri açıklamadan, olumlu bilgileri seçici bir şekilde ortaya çıartmak adına yeşile boyama stratejisini uygulamaktadır (Lyon ve Maxwell, 2011). İşletmelerin sergiledikleri bu tür yanıltıcı davranışlar ise tüketicilerin, yeşil pazardaki ürünlere karşı şüphe geliştirmesine neden olmaktadır (Pomering ve Johnson, 2009).

Yeşile boyama, artan yeşil satın alma ihtiyacı nedeniyle işletmelerin pazar paylarını artırmaları için daha yaygın bir yol haline gelmiştir (Chen ve Chang, 2013c; Horiuchi vd., 2009). Yeşile boyamanın artması, tüketicilerin tüm yeşil iddialara karşı şüpheciliğiyle sonuçlanacak ve tüketicilerin, iş operasyonları ve üretim faaliyetleri için işletmeleri yeşil sürdürülebilirliğe yöneltme gücünü zayıflatacaktır. Yeşile boyama, reklamcılıkta tüketici satın alma davranışını azaltacaktır çünkü tüketiciler karar vermek için genellikle işletmelerin pazarlama faaliyetlerine güvenmektedirler (Hamann ve Kapelus, 2004). Tüketiciler, işletmelerin yeşil iddialarına inanmadıkları takdirde, yeşil satın almalarını belirleyemezler. Bu bakımdan yeşile boyama, pazardaki yeşil pazarlamayı ve tüketicilerin yeşil satın alımlarını tehlikeye atacaktır.

Bu çalışma, işletmelerin kullanmış oldukları yeşile boyama yönteminin tüketici algısını nasıl değiştirdiğini belirlemek amacıyla gerçekleştirilmiştir. Yeşile boyama, tüketicilerin kafasını karıştırarak ve onları yeşil ürünler satın alma konusunda kararsız hale getirerek yeşil pazarlamaya zarar verebilmektedir. Nihayetinde böyle bir durumda tüketiciler çevreci ürünleri satın almayı bırakırlar. Sonuç olarak, yeşile boyama, tüketicilerin her yeşil iddiaya güvenmemesine neden olabilir. Bu nedenle, bir işletmenin yeşile boyamaya yönelik algıları, tüketicilerin bir işletmeye yönelik tutumunu yok edebilir. İşletmeler, yeşil pazardaki satışlarını artırmak, ürünlerinin çevresel özellikleri hakkındaki olumlu mesajları seçici bir şekilde açıklamak için olumsuz mesajlar vermeden yeşile boyamayı uygular (Lyon ve Maxwell, 2011). Bu durum, işletmelere karşı artan bir güvensizliğe neden olacaktır (Balmer vd., 2009). Marka imajını, tüketici sadakatini ve satın alma davranışını geliştirmek için işletmeler, yeşile boyama davranışlarını azaltmalı ve tüketicilerin, işletmelerin yeşil iddialarına karşı şüphelerini azaltacak yeterli mesaj almalarını sağlamalıdır (Hoedeman, 2002). Bu nedenle, işletmeler sadece "yeşil olduklarını" iddia etmemeli, yeşil ürünlerinin gerçekliği hakkında daha fazla sinyal vermelidir. Müşterilere güvenilir bilgi sağlamadan, işletmelerin tüketicilerini yeşil iddialarına ikna etmeleri kolay değildir (Chen, 2007). Literatür, satın alma davranışı ile ilgili çalışmaları geniş çapta tartışmış olsa da, çevre sorunları hakkındaki satın alma davranışını yeşile boyama, marka imajı ve marka sadakati perspektiflerinden inceleyen çalışmaların sayısı oldukça azdır. Dolayısıyla, bu çalışma özellikle yerli literatürdeki mevcut araştırma boşluğunu dolduracaktır. Çalışma, yeşil marka imajı ve yeşil marka sadakatinin, yeşil satın alma davranışı üzerindeki yeşile boyamanın etkisini daha fazla keşfetmek için ayrılmaz bir çerçevede birleştirmektedir. Çevreci davranışların arttı̆̆ı bu dönemde, işletmeler için yeşil satın alma davranışı önemli hale gelmiştir. Gerçekleştirilen çalışma işletmelerin yeşile boyama ile tüketicilerinin yeşil satın alma davranışları arasındaki negatif ilişkiyi araştırmaktadır. Ayrıca çalışma, yeşil marka imajının ve yeşil marka sadakatinin, işletmelerin yeşile boyama ve tüketicilerinin yeşil satın alma davranışı arasındaki negatif ilişki üzerindeki aracılık etkilerini de tartışmaktadır. Araştırma, işletmelerin yeşil satın alma davranışını geliştirmelerine ve yeşil pazarlamaya ilişkin literatürü daha da genişletmelerine yardımcı olmak için çevreciliğe uygun yeni bir perspektif önermektedir.

\section{LITERATÜR İNCELEMESİ VE HIPOTEZ GELIŞTIIRME}

\subsection{Yeşile Boyamanın Yeşil Marka Imajı Üzerindeki Olumsuz Etkisi}

İşletmeler, küresel çevreciliğin popülaritesi nedeniyle, çevresel sürdürülebilirliğe önem vermektedirler. Yeşil pazarlama, çevrenin korunmasına önem veren tüketicilere hitap etmenin kritik bir yolu haline gelmesinden dolayı birçok işletme, yeşil ürünlerini farklılaştırmak için yeşil imaj oluşturma arzusuna girmişlerdir (Chang, 2011). Yeşil imaj oluşturmak adına başvurulan faaliyetlerden biride yeşile boyamadır. Günümüzde birçok 
işletme, pazardaki yeşil fırsatları yakalamak ve çevre dostu olduklarını tüketicilere göstermek adına yeşile boyama faaliyetlerine yoğunlaşmaktadır (Laufer, 2003). Yeşile boyama, bir işletmenin ürünlerinin veya markalarının çevre dostu olduğu algısını teşvik etmek için yeşil pazarlamanın veya yeşil halkla ilişkilerin aldatıcı bir şekilde uygulandığı yanıltıcı bir davranıştır (Parguel vd., 2011). Özellikle son yıllarda küresel ısınmanın beraberinde getirdiği olumsuz doğa olaylarının etkisi, doğal kaynaklarının giderek azalması ve doğanın zarar görmesi gibi nedenlerin etkisiyle insanlar, doğanın korunmasına yönelik daha fazla farkındalık sahibi olmuşlardır. Tüketicilerdeki doğaya karşı saygı tutumunun gelişmesi, işletmeleri pazardaki yeşil fırsatları yakalamak ve kendilerini çevre dostu göstermek adına farklı yönelimlere itmiştir (Laufer, 2003; Kement ve Güçer, 2018). İşletmelerin yalancı yeşil iddialardan veya reklam faaliyetlerinden yararlanması sonucu ortaya çıkan yeşile boyama, tüketicilerin yeşil satın alma davranışı konusunda kafalarının karışmasına neden olmuştur (Balmer vd., 2009; Parguel vd., 2011). Böyle bir durumda ise gerçekten doğa dostu olan işletmelerin yeşil marka imajları, tüketicilerin şüpheleri sonucu zarar görebilmektedir (Polonsky vd., 2010).

Marka imajı, tüketiciler için mal veya hizmetleri ayırt etmenin zor olduğu daha karmaşık pazarlarda önemli bir rol oynar (Mudambi vd., 1997; Dağ ve Durmaz, 2020). İmaj, tüketicinin zihninde ürünle ilişkilendirilen bir markanın zihinsel resmini ifade eder ve markanın belirli özellikleriyle ilgili sembolik anlamlar içerir (Cretu ve Brodie, 2007; Padgett ve Allen, 1997; Demirağ ve Durmaz, 2020). Dahası, marka imajı, tüketicilerin belirli markalara karşı zihninde oluşturduğu algıların toplamını ifade eder (Cretu ve Brodie, 2007). Dolayısıyla marka imajı sembolik faydaları, fonksiyonel faydaları ve deneyimsel faydaları içerir (Park vd., 1986). Yeşil marka imajı ise en temelde, müşterinin zihninde çevresel özellikler ve kaygılarla bağlantılı bir markanın algılar kümesidir (Chen, 2010; Kement, 2019). Yeşile boyama, zihinde oluşan bu algıların güvenilir olmayan pazarlama faaliyetleri sonucunda sarsılmasına, yıkılmasına ve itibarsızlaştırılmasına neden olmaktadır (Ramus ve Montiel, 2005). Bunun sonucunda işletmeler ürünlerinin çevre dostu olduğunu iddia etseler bile tüketiciler yeşil iddialara güvenemeyeceklerdir (Lyon ve Maxwell, 2011). Bu tür olumsuz düşünceler tüketicinin işletme ve ürüne karşı negatif duygular beslemesine neden olmaktadır. Öte yandan yeşile boyama, tüketicinin algıladığı riski de olumsuz yönde etkileyecek ve bunun sonucunda çevresel kaygılar açısından tüketici tatmini ve sadakati azalacaktır (Dick ve Basu, 1994). Bu bilgiler ışığında aşağıdaki hipotez geliştirilmiştir;

Hı: Yeşile boyama, yeşil marka imajını negatif etkilemektedir.

\subsection{Yeşile Boyamanın Yeşil Marka Sadakati Üzerindeki Olumsuz Etkisi}

Sadakat, bir kişinin aynı ürünü veya markayı diğerlerinden ziyade defalarca satın alması anlamına gelmektedir (Oliver, 1999). Sadakat, yeniden satın alma veya yeniden satın alma taahhüdünü temsil etmektedir (Durmaz ve Dağ, 2018; Demirağ ve Durmaz, 2019). Sadakat ayrıca bir bireyin tekrar eden satın almalarına olan bağlılığının veya bu bağlılığının gücünü ölçmek için kullanılabilir (Dick ve Basu, 1994). Çevresel taahhütlerin ve kaygıların yaşandığı günümüz pazarlamasında yeni bir yapı olan yeşil sadakat, Chang ve Fong (2010) tarafından önerilerek literatüre kazandırılmıştır. Yeşil marka sadakati, müşterinin çevresel veya yeşil kaygıları içeren bir işletme ile ilişkisini sürdürmek istediği ve tercih edilen bir markayı gelecekte tutarlı bir şekilde yeniden satın almayı veya yeniden korumayı taahhüt etmesi olarak tanımlanmıştır (Çavuşoğlu vd., 2020). İşletmeler, yeşil ürünlerinin satışlarını artırmak ve müşterilerinin yeşil marka sadakatini artırmak için yeşil ürünlerinin işlevselliğini geliştirmektedir (Chen, 2013). Yeşile boyama, yeşil pazarlamayı engellemektedir, çünkü daha fazla tüketiciyi yeşil iddialar konusunda şüpheci hale getirecektir (Horiuchi vd., 2009). Chen ve Chang (2013b)'e göre tüketicilerin yeşile boyama algıları ile yeşil olarak algılanan riski arasında negatif bir ilişki vardır. Slaughter (2008) gerçekleştirmiş olduğu çalışmasında, yeşile boyamanın yeşil marka sadakati ile negatif olarak ilişkili olduğunu tespit etmiştir. Çevresel kaygı, tüketicilerin yeşil marka sadakatini etkileyecek önemli bir belirleyici haline gelmiştir (Chen, 2013). Gillespie (2008)'ye göre pazarda yeşile boyamanın popüler olması, tüketicilerin yeşil iddialara karşı güvensizlik duymasına sebep olmaktadır. Gillespie çalışmasında bu durumu yeşile boyamanın çevre koruma konusundaki tüketici sadakatini olumsuz etkileyeceği şeklinde belirtmiştir. Bu bilgiler ışığında aşağıdaki hipotez geliştirilmiştir;

$\mathrm{H}_{2}$ : Yeşile boyama, yeşil marka sadakatini negatif etkilemektedir.

\subsection{Yeşile Boyamanın Yeşil Satın Alma Davranışı Üzerindeki Olumsuz Etkisi}




\section{S. Çavuşoğlu 13/3 (2021) 2146-2161}

Yeşile boyama yeşil pazarlamanın büyümesini engelleyebileceğinden, tüketicilerin hangi yeşil girişimlerin daha güvenilir olduğunu ayırt etmesi kolay değildir (Horiuchi vd., 2009). Tüketiciler, bazı işletmelerin kendilerini genellikle yanılttığını ve çevresel iddialarını yerine getiremeyebileceklerini fark etmişlerdir (Ramus ve Montiel, 2005). Yeşile boyama, gerçek yeşil ürünlerin yaygınlığını engelleyeceği ve yeşil pazarlamanın etkinliğini azaltacağı için, işletmeler piyasadaki tüketicilere yanlış çevresel mesajlar vermekten kaçınmalıdır (Polonsky vd., 2010). Gillespie (2008) yeşile boyamayı, tüketicilerin yeşil satın alma davranışlarını gerçekleştirirken şüpheyle yaklaşmasına sebebiyet veren bir faaliyet olarak ifade etmiştir. Bu bakımdan tüketiciler, işletmelerin piyasadaki gerçek tüm yeşil iddialarına da güvenmeyecektir (Self vd., 2010). İşletmeler ancak yeşil girişimlerde aktif olarak yer alır ve çevresel çabalarını tüketicilerle başarılı bir şekilde iletirse, tüketiciler işletmelerin yeşil reklamlarına inanabilir (Chen ve Chang, 2013d; Chen ve Chang, 2013a; Horiuchi vd., 2009). İşletmeler ürünlerinin çevreye duyarlılığını abartması yani yeşile boyama faaliyetlerini arttırması durumunda müşteriler artık bu tür iddialara inanmayacaktır (Kalafatis vd., 1999). Bu nedenle, işletmeler, tüketicilerin yeşil pazarlama faaliyetlerine yönelik tutumlarına zarar verecektir (Parguel vd., 2011). Chen ve Chang (2013b)'e göre işletmeler, müşterilerini aldatmak için yeşile boyama faaliyetlerini kullanırlarsa, müşterileri ürünlerini pazardan satın almak istemezler. Ayrıca, yeşile boyama, belirli bir ürünün veya markanın çevresel mesajlarıyla ilgili olumsuz ağızdan ağza davranışın ortaya çıkmasına yol açacaktır (Ramus ve Montiel, 2005). Yeşil satın alma davranışı, bir tüketicinin çevresel ihtiyaçlarından kaynaklanan belirli bir mal veya hizmeti satın alacağ 1 anlamına gelmektedir (Chen ve Chang, 2012; Kement ve Bükey, 2020). Tüketicilerin yeşil satın alma davranışı, yeşile boyama faaliyetlerinden olumsuz etkilenmektedir (Chen ve Chang, 2013b). İlgili literatür yeşile boyama faaliyetinin tüketici satın alma davranışının belirleyicisi olduğunu varsaymaktadır (Kim ve Choi, 2005; Chen ve Chang, 2013b; Chen vd., 2015). Chen vd. (2020) yapmış oldukları çalışmalarında, yeşile boyamanın yeşil satın alma davranışını olumsuz etkilediği, aynı zamanda yeşil olarak algılanan kalite ve memnuniyetinde yeşile boyama davranışı ile olumsuz yönde ilişkili olduğu sonucuna ulaşmışlardır. Bu bilgiler ışında aşağıdaki hipotez geliştirilmiştir;

$\mathrm{H}_{3}$ : Yeşile boyama, yeşil satın alma davranışını negatif etkilemektedir.

\subsection{Yeşil Marka İmajının Yeşil Satın Alma Davranışı Üzerindeki Olumlu Etkisi}

Hu ve Wall (2005), çevresel imajdaki artışın rekabet gücünü artırabileceğini savunmaktadır. Sonuç olarak, yaygın tüketici çevreciliği ve katı çevre düzenlemelerinin yükselişinde işletmeler için yeşil marka imajı daha kritiktir (Chen, 2010). İşletmeler, farklılaşma avantajlarını oluşturmak için yeşil ürünlerinde yeşil pazarlama kavramını kullanmaktadır (Chen vd., 2006; Porter ve Van der Linde, 1995). Araştırmalar, tüketiciler tarafından algılanan imajın satın alma davranışlarını önemli ölçüde etkileyebileceğini göstermektedir (Chen, 2008; Dowling, 1986). Ayrıca, kendilerini yeşil marka imajlarını artırmaya adamış işletmeler, sadece çevresel cezalandırma sıkıntısını ortadan kaldırmakla kalmaz, aynı zamanda müşterilerinin yeşil satın alma davranışını yükseltmelerine de izin verir (Chen, 2010). Marka imajının, tüketicinin algıladığı riski zayıflatması ve aynı zamanda işlem anında satın alma niyetinin olasılığını artırması nedeniyle tüketici satın alma davranışı üzerinde olumlu bir etkisi vardır (Flavian vd., 2005). Dolayısıyla, ilgili alanyazın, marka imajının müşterilerin karar verme sürecini etkileyebileceğini göstermekte ve bu nedenle marka imajının müşteri satın alma davranışını olumlu yönde etkileyeceğini savunmaktadır (Tariq vd., 2013; Wang ve Tsai, 2014). Marka imajı, satın alma niyetlerinin önemli bir faktörüdür (Shah vd., 2012). Zayıf marka imajı, tüketicinin satın alma niyetini azaltacaktır (Tariq vd., 2013). Tüketiciler bir işletmenin marka imajını diğerlerinden daha iyi olduğunu algılarsa, ürünlerini satın almaya daha istekli olurlar (Wu vd., 2011). Çalışmalar, marka imajının satın alma davranışıyla olumlu bir şekilde ilişkili olduğunu göstermektedir (Dennis vd., 2007; Shah vd., 2012). Bu bilgiler ışığında aşağıdaki hipotez geliştirilmiştir;

$\mathrm{H}_{4}$ : Yeşil marka imajı, yeşil satın alma davranışını pozitif etkilemektedir.

\subsection{Yeşil Marka Sadakatinin Yeşil Satın Alma Davranışı Üzerindeki Olumlu Etkisi}

Tüketiciler bir ürüne veya markaya olan bağll1ıklarını önce bilişsel anlamda, daha sonra duygusal anlamda ve son olarak da davranışsal bir şekilde oluştururlar (Oliver, 1999). Müşteri sadakati, müşteri satın alma davranışının birincil öncülüdür (Souiden ve Pons, 2009). Dolayısıyla ilgili literatür, müşteri sadakatinin satın alma davranışıyla olumlu bir şekilde ilişkili olduğunu göstermektedir (Souiden ve Pons, 2009; Tariq vd., 2013; Yaseen vd., 2011). Müşteri sadakati, tüketici satın alma davranışının bir belirleyicisi olduğundan, alanyazında, işletmelerin müşteri satın alma davranışlarını artırmak için müşteri sadakatlerini geliştirecek kaynaklara 
yatırım yapmaları gerektiğini ileri sürmektedir (Chi vd., 2009). Son zamanlarda, daha fazla işletme, dürüst olmayan yeşil iddialarla ürünlerini tanıtmaktadır ve bu nedenle müşterilerin ürünlerini yeniden satın alma olasılıkları daha düşüktür (Kalafatis vd., 1999). İşletmeler pazardaki yeşil fırsatlardan yararlanmak istediğinden, sürdürülebilir kalkınmaya yönelik tüketici sadakati daha önemli bir rol oynamaktadır (Balmer vd., 2009). Chen (2010) sürdürülebilir kalkınmaya yönelik tüketici sadakatinin, çevresel sürdürülebilirlik açısından tüketici satın alma davranışını olumlu yönde etkileyeceğini ifade etmiştir. Bu bilgiler ışığında aşağıdaki hipotez geliştirilmiştir;

$\mathrm{H}_{5}$ : Yeşil marka sadakati, yeşil satın alma davranışını pozitif etkilemektedir.

\subsection{Yeşil Marka İmajı ve Yeşil Marka Sadakatinin Aracılık Etkisi}

Yeşile boyamanın yeşil marka imajıyla olumsuz bir şekilde ilişkili olduğu ve ayrıca yeşil marka imajının yeşil satın alma davranışını olumlu yönde etkilediği literatür incelemesi sonucunda tespit edilmiştir $\left(\mathrm{H}_{1}\right.$ ve $\mathrm{H}_{4}$ hipotezleri). Buna ek olarak, alanyazın, yeşile boyama faaliyetlerinin tüketicilerin yeşil satın alma davranışıyla olumsuz ilişkili olduğunu ortaya koymaktadır ( $\mathrm{H}_{3}$ hipotezi). Benzer şekilde yeşile boyamanın yeşil marka sadakatini olumsuz etkilediği ve ayrıca yeşil marka sadakatinin yeşil satın alma davranışını olumlu yönde etkilediği literatür taramasıyla desteklenmiştir $\left(\mathrm{H}_{2}\right.$ ve $\mathrm{H}_{5}$ hipotezleri). Bu nedenle, işletmelerin yeşile boyama faaliyetleri, tüketicilerin yeşil satın alma davranışını doğrudan etkilemekle kalmaz, aynı zamanda yeşil marka imajı ve yeşil marka sadakati yoluyla da etkileyebileceğini göstermektedir. Alanyazında her iki değişkenin aracılık ettiği sınırlı sayıda çalışma mevcuttur. Chen vd. (2020) yeşil ürünler satın alma deneyimi olan Tayvanlı tüketiciler üzerinden gerçekleştirmiş oldukları çalışmalarında, yeşil marka imajı ve yeşil marka sadakatinin yeşile boyama ve yeşil satın alma davranışı arasında kısmen aracılık ettiğini tespit etmişlerdir. Bu bilgiler ışında aşă̆ıdaki hipotezler geliştirilmiştir.

$\mathrm{H}_{6}$ : Yeşil marka imajı, yeşile boyama ile tüketicilerinin yeşil satın alma davranışı arasındaki negatif ilişkiye kısmen aracillk eder.

$\mathrm{H}_{7}$ : Yeşil marka sadakati, yeşile boyama ile tüketicilerinin yeşil satın alma davranışı arasındaki negatif ilişkiye kısmen aracillk eder.

Araştırma kapsamında oluşturulan model önerisi ve hipotezler Şekil 1'de detaylı olarak verilmektedir.

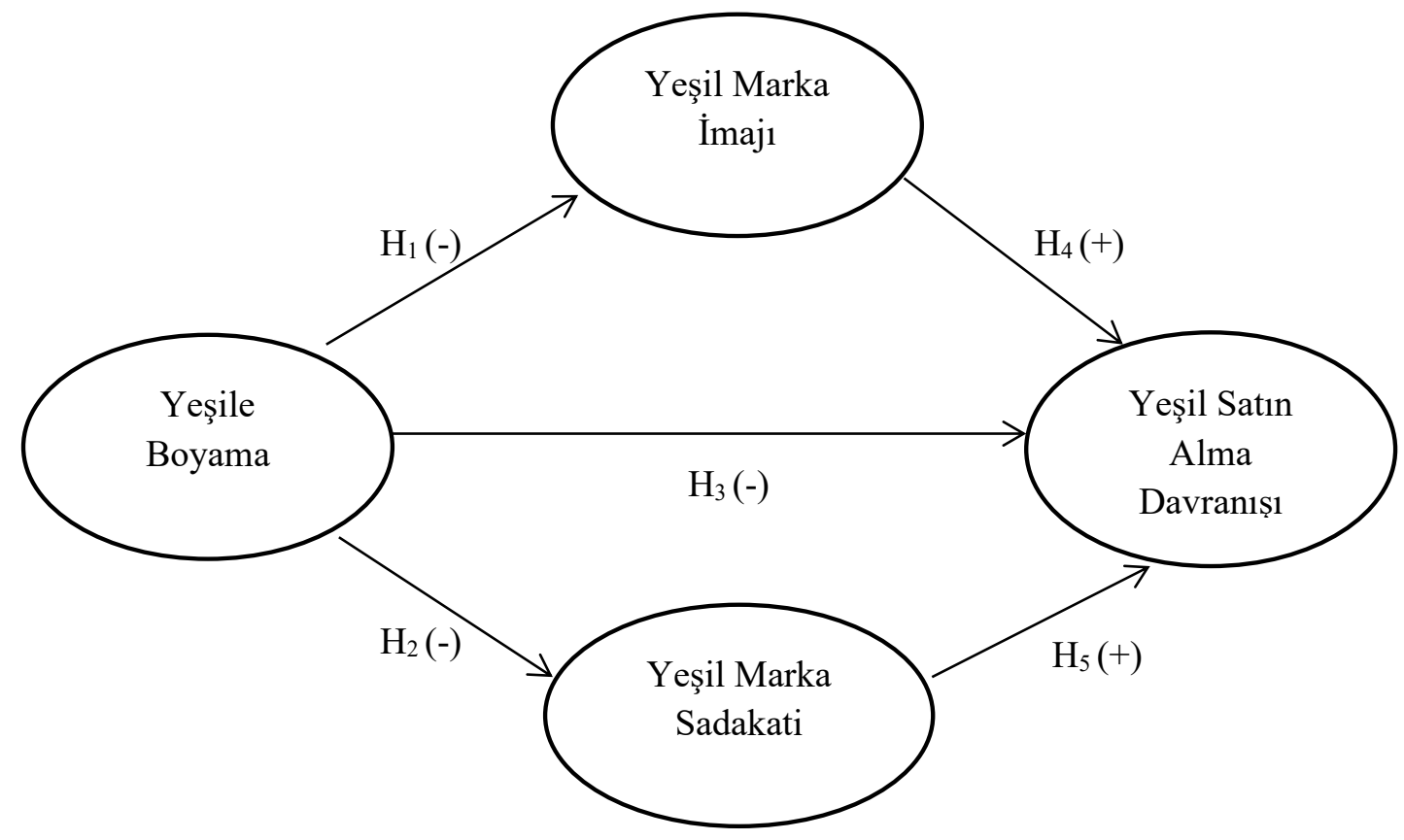

Şekil 1. Araştırma Modeli 


\section{Yöntem}

Çalışma, işletmeler tarafından gerçekleştirilen yeşile boyama faaliyetlerinin, tüketicilerin yeşil satın alma davranışları üzerinde etkisini araştırmak amacıyla gerçekleştirilmiştir. Çalışmada ayrıca yeşil marka imajı ve yeşil marka sadakatinin yeşile boyama faaliyetleri ile yeşil satın alma davranışı üzerinde nasıl bir aracı etkiye sahip olduğu belirlenmeye çalışılmıştır. Evrenin geniş bir alanı kapsaması nedeniyle araştırmada tesadüfi olmayan örneklem metotlarından "kolayda örneklem yöntemi" kullanılarak veriler toplanmıştır. Türkiye'de yeşil ürünler satın alma deneyimi olan tüketicilerin hem tamamına ulaşmanın mümkün olmaması, hem de Covid-19 kaynaklı pandemi önlemleri sebebiyle daha hızlı veri toplanması amacıyla (Malhotra, 2004) kolayda örneklem yöntemi seçilmiştir. Örneklem büyüklüğünün hesaplanması için, Ural ve Kılıç (2006) tarafından ifade edilen; "10.000' den büyük evrenler için 384 sayısı yeterli" görüşü doğrultusunda planlama yapılmış ve toplamda 410 anket formu 1 Ocak-1 Şubat 2021 tarihleri arasında çevrimiçi toplanmıştır. Anketler Google formlar vasıtasıyla oluşturulmuş, e-posta ve WhatsApp uygulaması olan çevrimiçi platformlar kullanılarak dağıtılmıştır.

Araştırmada kullanılan anket formu iki bölümden oluşmaktadır. Birinci bölümde katılımcıların demografik özelliklerini açıklamada kullanılan; cinsiyet, yaş aralığı, eğitim seviyesi, medeni durum ve gelir seviyesine yönelik algı soruları kategorik olarak yöneltilmiştir. Anket formunun ikinci bölümünde değişkenleri ölçmeye yönelik ifadelere yer verilmiştir. Yeşile boyama değişkenine ait 5 ifadeyi ölçmek için Chen ve Chang (2013a), yeşil marka imajı değişkenine ait 5 ifadeyi ölçmek için Chen (2010) ve yeşil marka sadakati değişkenine ait 4 ifadeyi ölçmek için Chen (2013) tarafından geliştirilen ölçekler kullanılmıştır. Yeşil satın alma davranışı değişkenine ait 3 ifadeyi ölçmek için Kim ve Choi (2005) tarafından geliştirilen ölçek kullanılmıştır. Tüm ifadeler beşli likert tipi olacak şekilde "kesinlikle katılmıyorum" (1), "kesinlikle katılıyorum" (5) aralığında katılımcılara yöneltilmiştir.

SmartPLS 3 yapısal eşitlik modellemesi veri analizi için kullanılmıştır. PLS, son yıllarda veri işleme için popüler yöntemlerden birisi haline gelmiştir. Hair vd. (2011), bağımlı değişkenlerin etkilerini tahmin etmek için PLS-SEM kullanılmasını önermektedir. Benzer şekilde Davari ve Rezazadeh (2013), bu yöntemin kullanılmasının, önerilen araştırma modeli için bir grup denklemi eş zamanlı olarak tahmin etmek için uygun olduğunu ve değişkenler arasındaki ilişkiyi geliştirdiğini öne sürmüşlerdir. SEM, araştırmacıların yapılar arasındaki ilişkileri incelemesini sağlayarak zor ve gözlemlenemeyen gizli yapıları analiz etmesi, doğrudan ve dolaylı yolları ölçmek için en iyi yaklaşım olarak kabul edilmektedir (Vinzi vd., 2010). Bu nedenle, çalışma için SmartPLS veri analiz yöntemi seçilmiştir. Ölçeklerin öncelikle formatif veya reflektif yapılardan hangisine uyumlu olduğunu belirlemek için doğrulayıcı Tetrad analizi (CTA) uygulanmıştır (Bknz Tablo 1). Ölçüm modelinin yapısına göre kovaryans bazlı veya kısmi en küçük kareler bazlı yapısal eşitlik modeli kullanilacaktır.

Tablo 1. Doğrulayıcı Tetrad Analizi

\begin{tabular}{lll}
\hline Değişkenler & CI Low & CI Up \\
\hline Yeşile Boyama & & 0,078 \\
\hline 1: boyama1,boyama2,boyama3,boyama4 & $-0,306$ & 0,014 \\
\hline 2: boyama1,boyama2,boyama4,boyama3 & $-0,006$ & 0,008 \\
\hline Yeşil Marka Imaji & & 0,015 \\
\hline 1: imaj1,imaj2,imaj3,imaj4 & $-0,079$ & \\
\hline 2: imaj1,imaj2,imaj4,imaj3 & $-0,080$ & 0,082 \\
\hline Yeşil Marka Sadakati & & 0,160 \\
\hline 1: sadakat1,sadakat2,sadakat3,sadakat4 & $-0,075$ & \\
\hline 2: sadakat1,sadakat2,sadakat4,sadakat3 & $-0,012$ & \\
\hline
\end{tabular}

Alt ve üst sınırların tamamı tüm göstergeler için negatif veya alt ve üst sınırların tamamı pozitifse "Formative" ölçüm modeli uygulanır. Bir veya daha fazla gösterge için alt sınırın negatif ve üst sınırın pozitif olması durumunda "Reflective" ölçüm modeli uygulanır (Sönmez Çakır, 2020). Analizde yeşile boyama, yeşil marka imajı ve yeşil marka sadakati yer almaktadır. Tetrad analizi 4 ve üzeri ifadesi bulunan değişkenleri hesaplamaktadır. Bu bakımdan yeşil satın alma davranışında 3 ifade yer aldığ hesaplanmamıştır. Yapılan CTA analizi sonuçları incelendiğinde değişkenlerin güven aralıklarının 0 olduğu ve alt sınırın negatif-üst sınırın pozitif olması durumu göz önünde bulundurularak yapının "reflektif" yapıya 
sahip olduğu tespit edilmiştir. Bu bağlamda araştırmada Smart PLS istatistik programında analiz aşamalarında kovaryans bazlı Smart PLSc yöntemi kullanılmıştır.

\section{Bulgular}

\subsection{Demografik Bulgular}

Araştırmaya katılan bireylerin demografik özellikleri Tablo 2'de detaylı olarak verilmektedir. Katılımcıların $\% 45,1^{\prime} i$ erkek, $\% 54,9^{\prime}$ u kadındır. Medeni durum incelendiğinde bireylerin $\% 52,2$ sinin evli olduğu tespit edilmiştir. Yaş dağılımlarına bakıldığında, en fazla katılımın \%43,2 ile 25-34 yaş aralığında olduğu görülmektedir. Katılımcıların \%40,5'inin lisans düzeyinde eğitim aldıkları, gelir durumu algıları incelendiğinde ise bireylerin $\% 69,8^{\prime}$ inin orta düzeyde gelire sahip oldukları tespit edilmiştir.

Tablo 2. Katılımcıların Demografik Özellikleri

\begin{tabular}{|c|c|c|c|}
\hline Kategoriler & & $\mathbf{n}$ & $\%$ \\
\hline \multirow{2}{*}{ Cinsiyet } & Kadın & 225 & 54,9 \\
\hline & Erkek & 185 & 45,1 \\
\hline \multirow{2}{*}{ Medeni Durum } & Evli & 214 & 52,2 \\
\hline & Bekâr & 196 & 47,8 \\
\hline \multirow{7}{*}{ Yaş } & 18 yaş altı & 14 & 3,4 \\
\hline & $18-24$ & 105 & 25,6 \\
\hline & $25-34$ & 177 & 43,2 \\
\hline & $35-44$ & 59 & 14,4 \\
\hline & $45-54$ & 42 & 10,2 \\
\hline & $55-64$ & 10 & 2,4 \\
\hline & 65 ve üzeri & 3 & 0,7 \\
\hline \multirow{5}{*}{ Eğitim } & İlköğretim & 19 & 4,6 \\
\hline & Lise & 100 & 24,4 \\
\hline & On lisans & 92 & 22,4 \\
\hline & Lisans & 166 & 40,5 \\
\hline & Yüksek lisans/Doktora & 33 & 8,0 \\
\hline \multirow{4}{*}{ Gelir Durumu Algısı } & Düşük & 64 & 15,6 \\
\hline & Orta & 286 & 69,8 \\
\hline & Yüksek & 50 & 12,2 \\
\hline & Çok yüksek & 10 & 2,4 \\
\hline
\end{tabular}

\section{2. Ölçüm Modelinin Test Edilmesi}

PLS-SEM, iç-dış model analizlerinden oluşmaktadır. Bu bakımdan değerlendirme iki bölüme ayrılmıştır. Birinci bölümde, dışsal model veya dış model, iç tutarlık güvenilirlik katsayıları, birleşme geçerliliği ve ayırt edici geçerlilik ile değerlendirilmiştir (Ghozali ve Latan, 2015). İkinci bölümde ise yol analizi için iç model değerlendirilmiştir. İç tutarlık güvenilirliği için birleşik güvenilirlik (Composite Reliability-CR) değerleri hesaplanmış ayrıca güvenilirliğin sağlanması kapsamında Cronbach Alpha (CA) ve Rho_A kullanılmıştır. Birleşme geçerliliği için faktör yükleri $(\lambda)$ ve açıklanan ortalama varyans (Average Variance Extracted-AVE), ayrışma geçerliliği için ise Fornell-Larcker ölçütü (Fornell-Larcker Criterion) ile HTMT katsayıları (Heterotrait-Monotrait Ratio) uygulanmıştır. 
Tablo 3. Güvenirlik ve Geçerlik

\begin{tabular}{|c|c|c|c|c|}
\hline Değişkenler & $\lambda$ & t-değgeri & CR & AVE \\
\hline Yeşile Boyama $(\mathrm{YB})(\mathrm{CA}=0.98)$ & & & .98 & .94 \\
\hline 1 X markasının çevresel özelliklerine ilişkin ifadeleri yanıltıcıdır. & .980 & 170.746 & & \\
\hline $2 X$ markası çevresel özelliklerine ilişkin görsellerinde veya grafiklerinde yanıltıcıdır. & .974 & 143.399 & & \\
\hline X markası çevreye yönelik faydasında net olmayan iddialara sahiptir. & .938 & 74.117 & & \\
\hline $4 X$ markası yeşil ürün olma performansını abartmaktadır. & .976 & 150.897 & & \\
\hline $\begin{array}{l}\text { X markası yeşil olma iddiasını daha önemli göstermek için önemli bilgileri } \\
\text { saklamaktadır. }\end{array}$ & .980 & 176.362 & & \\
\hline Yeşil Marka İmajı (YMİ) $(C A=0.87)$ & & & .87 & .58 \\
\hline 1 X markası, sürdürülebilir kalkınmanın en iyi ölçütü olarak kabul edilmektedir. & .800 & 24.304 & & \\
\hline 2 X markası yeşil itibar konusunda uzmanlaşmıştır. & .804 & 27.007 & & \\
\hline 3 X markası çevresel özellikler konusunda mükemmeldir. & .769 & 14.844 & & \\
\hline $4 X$ markası çevresel performans konusunda olağanüstüdür. & .733 & 13.128 & & \\
\hline 5 X markası, sürdürülebilir kalkınma konusunda güvenilirdir. & .701 & 11.774 & & \\
\hline Yeşil Marka Sadakati (YMS) (CA=0.90) & & & .90 & .69 \\
\hline 1 Çevresel performansı nedeniyle X markasını yeniden satın almaya hevesliyim. & .871 & 32.986 & & \\
\hline $\begin{array}{l}2 \text { Çevresel işlevselliği nedeniyle X markasını diğer markalara satın almayı tercih } \\
\text { ediyorum. }\end{array}$ & .878 & 50.135 & & \\
\hline $\begin{array}{l}\text { X markasının çevresel özellikleri nedeniyle nadiren başka markalara geçmeyi } \\
\text { düşünürüm. }\end{array}$ & .851 & 40.779 & & \\
\hline 4 X Markası çevre dostu olduğu için satın almaya devam etmek niyetindeyim. & .729 & 18.286 & & \\
\hline Yeşil Satın Alma Davranışı (YSAD) $(C A=0.90)$ & & & .90 & .76 \\
\hline 1 X markasını çevresel kaygılar nedeniyle satın alıyorum. & .845 & 35.275 & & \\
\hline 2 Çevresel performansından dolayı gelecekte X markasını satın alacă̆ım. & .894 & 59.991 & & \\
\hline Genel olarak, çevre dostu oldŭ̆u için X markasını satın aldığım için mutluyum. & .876 & 53.602 & & \\
\hline
\end{tabular}

Çalışmada kullanılan maddelerin benzer yapıları ölçüp ölçmediğini belirlemek için iç tutarlılık güvenilirliği analizi kullanılmıştır (Hair vd., 2016). İç tutarlılık güvenilirliğini belirlemek için bileşik güvenilirlik (Composite Reliability-CR), Cronbach alfa ve Rho_A değerleri kullanılarak değerlendirilmiştir. Nunnally ve Bernstein (1994)'ne göre, 0,6 ile 0,7 arasındaki CR değerleri, keşif çalışmaları için kabul edilebilirken, daha sonraki çalışmalar için 0,7 üzeri değerlerin tatmin edici olarak kabul edilebileceğini belirtmişlerdir (Hair vd., 2016; Gefen vd., 2000). Cronbach alfa ve Rho_A (CA ve Rho_A> 0.7) bir yapıyı ölçen maddelerin güvenilirliğinin bir ölçüsüdür (Nunnally ve Bernstein, 1994). Tablo 3, bu çalışmadaki her bir yapı için Cronbach alfa (CA), Rho_A ve CR değerlerini göstermektedir. Çalışmada bu değerler kabul edilebilir bir aralıkta bulunmuştur.

Çalışmada bir maddenin benzer yapıları ne kadar iyi ölçebileceğini görmek için birleşme geçerliliği analizi uygulanmıştır (Hair vd., 2016). Birleşme geçerlilik analizi iki test ile değerlendirilmektedir; faktör yükleri ve açıklanan ortalama varyans (Average Variance Extracted-AVE). Faktör yüklerinin değerlendirme kriteri 0.50'nin üzerindeki değerlerdir (Kaiser, 1974). AVE değeri benzer şekilde 0,50' den büyük olmalıdır (Hair vd., 2019). Gerçekleştirilen analizler neticesinde her bir ifadenin faktör yükü ve her bir yapının AVE değeri 0.50'nin üzerinde belirlenmiştir.

Test edilen yapıların diğer yapılardan ne kadar farklı olduğunu değerlendirmek için ayrışma geçerliliği analizi yapılmıştır. Bu analiz, bir yapının başka bir yapıyla ne kadar ilişkili olduğunu ve tek bir yapıyı kaç öğenin temsil edebileceğini belirleyebilmektedir (Hair vd., 2016). Çalışmada ayrışma geçerliliğini ölçmek için analiz edilen iki test gerçekleştirilmiştir; Fornell-Larcker ve HTMT oranı. Fornell-Larcker kriteri, AVE karekök değerini, herhangi bir sütun veya satırdaki en yüksek değeri gösteren yapı korelasyon değeri ile diğer herhangi bir yapının en yüksek korelasyon değerine kıyasla karşılaştırmaya yönelik bir analizdir (Hair vd., 2019). Bu yöntem, gizil değişkenlerin diğer gizil değişkenlere göre madde değişkeni için daha iyi açıklama yapması gerektiği görüşüne dayanmaktadır. 
Tablo 4. Ayrışma Geçerliliği Analizi Sonuçları (Fornell-Larcker Kriteri)

\begin{tabular}{llcccccc}
\hline \multicolumn{2}{l}{ Değişkenler } & $\overline{\mathbf{x}}$ & s.s. & $\mathbf{1}$ & $\mathbf{2}$ & $\mathbf{3}$ & $\mathbf{4}$ \\
\hline $\mathbf{1}$ & YB & 2,17 & 1,33 & $\mathbf{9 7 0}$ & & & \\
$\mathbf{2}$ & YMİ & 3,78 &, 734 &,- 594 & $\mathbf{7 6 2}$ & & \\
$\mathbf{3}$ & YMS & 3,75 &, 860 &,- 431 &, 722 & $\mathbf{8 3 5}$ &, 827 \\
$\mathbf{4}$ & YSAD & 3,85 &, 935 &,- 444 &, 752 & $\mathbf{8 7 2}$ \\
\hline
\end{tabular}

Not: Koyu olarak yazılmış değerler $\sqrt{A V E}$ karekökünü göstermektedir.

HTMT oranı, Fornell ve Larcker kriterinin doğruluğunu test etmek amaciyla tercih edilmektedir. HTMT değerinin 0.85 (Kline, 2011), 0.90 (Gold vd., 2001) veya değerlerin 1.00'ın (Henseler vd., 2016) altında olması gerekliliği belirtilmiştir. Gerçekleştirilen analizler neticesinde test edilen her yapı için ayırt edici geçerliliğin doğruluğu kanitlanmıştır.

Tablo 5. Ayrışma Geçerliliği Analizi Sonuçları (HTMT)

\begin{tabular}{lllll}
\hline Değişkenler & $\mathbf{1}$ & $\mathbf{2}$ & $\mathbf{3}$ & $\mathbf{4}$ \\
\hline $\mathbf{1}$ & YB & & & \\
$\mathbf{2}$ & YMI & 0,593 & & \\
$\mathbf{3}$ & YMS & 0,431 & 0,782 & 0,847 \\
$\mathbf{4}$ & YSAD & 0,844 & 0,756 & \\
\hline
\end{tabular}

Araştırma modelinin uyum iyiliği değerleri için standartlaştırılmış ortalama karekök (Standardized Root Mean Square Residual-SRMR) değeri incelenmiştir. Henseler vd. (2016) ve Cho vd. (2020)'ne göre, SRMR değeri 0,08'den düşük olmalıdır (100'den büyük bir örneklem boyutu için). Böylece, bu çalışma için anlamlı bir model uyumu tespit edilmiştir (0.034).

\subsection{Yapısal Modelin İncelenmesi}

Smart-PLS modelinin çalışmasının bir sonraki adımı, iç modelin veya yolların değerlendirilmesidir. Bir iç modelin değerlendirilme süreci çoklu bağlantı analizi (VIF), determinasyon katsayısı $\left(R^{2}\right)$, etki büyüklüğü analizi $\left(f^{2}\right)$, tahmin gücü analizi $\left(\mathrm{Q}^{2}\right)$ ve yol katsayısı analizleri ile mümkün olmaktadır. VIF, regresyon modelinde bir bağımsız değişken ile diğer bağımsız değişkenin çoklu doğrusallık problemi olup olmadığının bir ölçütü olarak kabul edilmektedir (O'brien, 2007). VIF değerlerinde farklı aralıklar değerlendirmeye alınmış, Diamantopoulos ve Siguaw (2006)'a göre 3 ün altı, Hair vd. (2011)'ne göre 5'in altı, Smith vd. (2020)'ne göre 10'un altındaki VIF değerlerinin çoklu doğrusallık sorunu oluşturmayacağı belirtilmiştir. Çalışmada elde edilen sonuçlar doğrultusunda VIF değerlerinin uygun değerlere sahip olduğu belirlenmiştir (Tablo 6).

$R^{2}$ testi, bağımlı değişkenin açıklayıcı değişkenleri nasıl etkilediğini tanımlamaktadır. $R^{2}$ değeri 0,75 veya daha yüksekse, bağımsız değişkenlerin bağımlı değişken üzerinde önemli bir etkisi olduğu anlamına gelir. $R^{2}$ değeri 0,5 ise orta düzeyde bir etkiyi, 0,25 veya daha az olduğunda ise zayıf bir etkiyi ifade etmektedir (Hair, 2011). Mevcut araştırmadaki $\mathrm{R}^{2}$ değerleri bağımsız değişkenlerin bağımlı değişkenler üzerinde genel olarak önemli bir etkisinin olduğunu göstermektedir (Tablo 6). Yapısal modelin değerlendirilme süreci etki büyüklüğü analizi olan $\mathrm{f}^{2}$ ile devam etmiştir. Etki büyüklüğü analizinde bağımsız değişkenlerin bağımlı değişkenlerin açıklanma oranındaki paylarını göstermektedir. $\mathrm{f}^{2}$ değeri $0,02^{\prime}$ nin altında veya eşdeğeri ise, düşük bir etki anlamına gelmektedir. $\mathrm{f}^{2}$ 0,15 ve üzeri değeri gösteriyorsa orta etkiyi, 0,35 ve üzeri ise güçlü bir etkiyi göstermektedir (Cohen, 1988). Mevcut araştırmada f2 genel olarak orta ve yüksek etki derecesine sahiptir. Bu durum gizil değişkenlerin orta-güçlü düzeyde etkiye sahip olduğunu göstermektedir (Tablo 6). Tahmin gücü analizi $\mathrm{Q}^{2}$ (Blindfolding), veri kapama yöntemi ile modelin tahmin etme gücünü hesaplayan bir metottur. Bu analiz sadece reklektif değişkenler içeren modeller için uygundur. Analiz bağımlı değişkenleri indikatörlerine ait tüm gözlemlerin döngüsel olarak kapatılıp tekrar hesaplanması ile gerçekleşmektedir. $\mathrm{Q}^{2}$ katsayısının 0'dan farklı bir değer alması gerekmektedir. Katsayı 0,02 ve üzerinde ise küçük, 0,15 ve üzerinde olması orta, 0,35 ve üzerinde olması büyük tahmin edicilik olarak değerlendirilmektedir (Sönmez Çakır, 2020). Yapılan analizler sonucunda elde edilen $\mathrm{Q}^{2}$ değerleri tahmin gücünün genel olarak orta ve büyük tahmin edicilik düzeyde olduğunu göstermektedir (Tablo 6).

Yapısal model ön değerlendirmeler tamamlandıktan sonra araştırma hipotezlerinin testine geçilmiştir. Elde edilen sonuçlar Tablo 6'da detaylı olarak verilmektedir. 
S. Çavuşoğlu 13/3 (2021) 2146-2161

Tablo 6. Yapısal Değerlendirme (Hipotez Testi)

\begin{tabular}{|c|c|c|c|c|c|c|c|c|c|}
\hline & Hipotezler & $\begin{array}{c}\text { Standardize } \\
\beta\end{array}$ & $\begin{array}{c}\text { Standart } \\
\text { Sapma }\end{array}$ & t-değgeri & $p$-değeri & $V I F$ & $f^{2}$ & $Q^{2}$ & $R^{2}$ \\
\hline $\mathrm{H}_{1}$ & YB »>YMI & -0.594 & 0.043 & 13.809 & $0.000^{* * *}$ & 1.000 & 0.545 & 0.19 & 0.35 \\
\hline $\mathrm{H}_{2}$ & YB $\gg \gg$ YMS & -0.431 & 0.049 & 8.802 & $0.000^{* * *}$ & 1.000 & 0.228 & 0.12 & 0.18 \\
\hline $\mathrm{H}_{3}$ & YB»»YSAD & -0.330 & 0.039 & 7.137 & $0.000^{* * *}$ & 1.551 & 0.002 & 0.52 & 0.73 \\
\hline $\mathrm{H}_{4}$ & 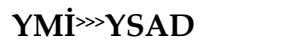 & 0.212 & 0.081 & 2.603 & $0.009^{* *}$ & 3.246 & 0.053 & & \\
\hline $\mathrm{H}_{5}$ & YMS $\gg>Y S A D$ & 0.668 & 0.078 & 8.537 & $0.000^{* * *}$ & 2.581 & 0.662 & & \\
\hline $\mathrm{H}_{6}$ & YB $\gg \gg Y M \dot{I} \gg \gg Y S A D$ & -0.126 & 0.049 & 2.542 & $0.011^{*}$ & & & & \\
\hline $\mathrm{H}_{7}$ & $Y B^{\gg \gg>Y M S} S^{\gg>Y Y A D}$ & -0.288 & 0.046 & 6.223 & $0.000^{* * *}$ & & & & \\
\hline
\end{tabular}

Gerçekleştirilen yapısal eşitlik modeli sonuçlarına göre yeşile boyama, yeşil marka imajı (BYB-YMI=-0.594, $\mathrm{t}=13.809, \mathrm{p}<0.001$ ), yeşil marka sadakati (BYB-YMS=-0.431, $\mathrm{t}=8.802, \mathrm{p}<0.001$ ) ve yeşil satın alma davranışını ( $B Y B-Y S A D=-0.330, t=7.137, p<0.001$ ) negatif yönde etkilemektedir. Dolayısıla $\mathrm{H}_{1}, \mathrm{H}_{2}$ ve $\mathrm{H}_{3}$ hipotezleri kabul edilmiştir. Yeşil marka imajı ( $($ YMI-YSAD $=0.212, \mathrm{t}=2.603, \mathrm{p}<0.01$ ) ve yeşil marka sadakati ( $(\mathrm{YMS}-\mathrm{YSAD}=0.668$, $\mathrm{t}=8.537, \mathrm{p}<0.001$ ) yeşil satın alma davranışını pozitif yönde etkilemektedir. Dolayısıyla $\mathrm{H}_{4}$ ve $\mathrm{H}_{5}$ hipotezleri kabul edilmiştir.

Çalışma kapsamında yeşil marka imajı ve yeşil marka sadakatinin, yeşile boyama ile yeşil satın alma davranışı arasında aracılık etkisi tespit edilmeye çalışılmıştır. Zhao vd. (2010), dolaylı etkilerin anlamlı olması durumunda aracı etki durumundan bahsedilebileceğini ifade etmişlerdir. Zhao vd.'ne göre dolaylı ve direkt etkilerin anlamlı, toplam etkilerin pozitif veya negatif çıkması durumunda kısmi aracılık etkisinden söz edilebileceğini belirtmişlerdir. Eğer dolaylı etki anlamlı ve direkt etki anlamsız ise bu durumda tam aracılık etkisinden bahsedilebilir. Gerçekleştirilen analizler neticesinde yeşil marka imajı (BYB $>>Y M I>Y Y S A D=-0.126$, $\mathrm{t}=2.542$, $\mathrm{p}<0.05$ ) ve yeşil marka sadakatinin ( $\mathrm{BYB} \gg>\mathrm{YMS} \gg>\mathrm{YSAD}=-0.288, \mathrm{t}=6.223, \mathrm{p}<0.001$ ), yeşile boyama ile yeşil satın alma davranışı arasında negatif kısmi aracılık etkisi tespit edilmiştir. Dolayısıyla $\mathrm{H}_{6}$ ve $\mathrm{H}_{7}$ hipotezleri kabul edilmiştir. Aracılık etkiye sahip olan "yeşil marka imajı" değişkeninin aracılık etki boyutu VAF (Variance Accounted For) değeri ile ayrıca hesaplanmıştır. Dolaylı etkilerin toplam etkilere bölünmesi ile elde edilen VAF değerleri (Nitzl ve Hirsch, 2016) 0.20'nin altında ise sıfır aracilık, 0.20-0.80 arasında kısmi aracılık ve $0.80^{\prime}$ den fazla ise tam aracılık etkiden söz edilebilir (Hair vd., 2016). Yapılan analizler sonucunda

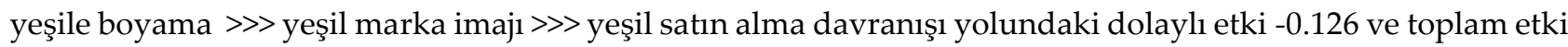
-0.444 olarak hesaplanmıştır. Bu doğrultuda VAF değeri (-0.126/-0.444) “0.57" olarak hesaplanmış ve yeşil marka imajının negatif yönde "kısmi aracılık (rekabetçi)" etkisi tespit edilmiştir.

Tablo 7. Yapısal Modelde Dolaylı ve Doğrudan Etki

\begin{tabular}{|c|c|c|c|}
\hline \multirow{2}{*}{ Bağımsız Değişkenler } & \multicolumn{3}{|c|}{ Bağımlı Değişkenler } \\
\hline & YSAD & YMİ & YMS \\
\hline \multicolumn{4}{|l|}{ YB } \\
\hline Doğrudan Etki & $-0.330^{* * *}$ & & \\
\hline Dolaylı Etki & & $-0.126^{*}$ & \\
\hline $\begin{array}{l}\text { Toplam Etki } \\
\text { YB »» YMI } \gg \text { YSAD }\end{array}$ & $-0.444^{* * *}$ & & \\
\hline \multicolumn{4}{|l|}{ YB } \\
\hline Doğrudan Etki & $-0.330^{* * *}$ & & \\
\hline Dolaylı Etki & & & $-0.288^{* * *}$ \\
\hline $\begin{array}{l}\text { Toplam Etki } \\
\text { YB } \gg>\text { YMS } \gg>\text { YSAD }\end{array}$ & $-0.444^{* * *}$ & & \\
\hline
\end{tabular}

Yapılan analizler sonucunda yeşile boyama $\gg>$ yeşil marka sadakati $\gg>$ yeşil satın alma davranışı yolundaki dolaylı etki -0.288 ve toplam etki - 0.444 olarak hesaplanmıştır. Bu doğrultuda VAF değeri (-0.288/-0.444) “ 0.73 ” 
olarak hesaplanmış ve yeşil marka sadakatinin negatif yönde kısmi aracılık (rekabetçi) etkisi benzer şekilde tespit edilmiştir.

\section{Sonuç ve Tartışma}

Araştırma, işletmeler tarafından gerçekleştirilen yeşile boyamanın tüketicilerin yeşil satın alma davranışları üzerinde etkisini araştırmak amacıyla gerçekleştirilmiştir. Çalışmada ayrıca yeşil marka imajı ve yeşil marka sadakatinin yeşile boyama faaliyeti ile yeşil satın alma davranışı üzerinde nasıl bir aracı etkiye sahip olduğu belirlenmeye çalışılmıştır. Oluşturulan hipotezler ayrıntılı bir literatür taramasıyla desteklenmiş ve araştırma modeli önerilmiştir. Araştırma modeli test edilmeden önce ölçüm modeli ve yapısal model analize tabi tutulmuştur. Gerçekleştirilen analizler neticesinde ölçüm modelinin Reflective yapıya uygun olduğu görülmektedir. Bu bakımdan PLS ölçüm modelinin değerlendirmesi sürecinde iç tutarlık güvenilirliği, birleşme geçerliliği ve ayrışma geçerliliği analizleri uygulanmıştır. Yapısal modelin değerlendirilmesi sürecinde VIF, R², Q², f² ve yol katsayısı analizleri gerçekleştirilmiştir.

Gerçekleştirilen yol analizi neticesinde $\mathrm{H}_{1}, \mathrm{H}_{2}$ ve $\mathrm{H}_{3}$ hipotezleri kabul edilmiştir. Yeşile boyamanın, yeşil marka imajı, yeşil marka sadakati ve yeşil satın alma davranışını negatif yönde etkilediği belirlenmiştir. Elde edilen sonuçlar alanyazında gerçekleştirilen çalışmalarla (Ramus ve Montiel, 2005; Lyon ve Maxwell, 2011; Dick ve Basu, 1994; Chen ve Chang, 2013b; Slaughter, 2008; Chen, 2013; Gillespie, 2008; Self vd., 2010; Kalafatis vd., 1999; Ramus ve Montiel, 2005; Kim ve Choi, 2005; Chen vd., 2015) paralellik göstermektedir. Ramus ve Montiel (2005) yeşile boyamanın marka imajını olumsuz etkileyeceğini belirtmişlerdir. Slaughter (2008) gerçekleştirmiş olduğu çalışmasında yeşile boyamanın yeşil marka sadakatini olumsuz etkilediğini tespit etmiştir. Chen (2013), yeşile boyama gibi olumsuz iddiaların çevresel kaygıya sebep olacağının ve bu durumun yeşil marka imajı ve sadakatini olumsuz yönde etkileyeceğini belirtmiştir. Chen ve Chang (2013b) yeşile boyama faaliyetlerinin müşterileri aldatmak anlamına geldiğini, işletmelerin bu iddiaları kullanmaları halinde yeşil satın alma davranışlarının olumsuz etkileneceğini ifade etmişlerdir. Kim ve Choi (2015) ve Chen vd. (2015) benzer şekilde yeşile boyamanın yeşil satın alma davranışını olumsuz etkilediğini yapmış oldukları çalışmalarında tespit etmişlerdir. Yeşil pazarlama faaliyetlerinin daha etkili hale gelmesi ve yeşil ürünlerin pazarda başarılı bir şekilde tanıtılabilmesi için işletmelerin yeşile boyama faaliyetlerini en aza indirmeleri gerekmektedir. Bu çalışma, yeşile boyamanın üç negatif öğesinin olduğunu ortaya koymaktadır. Birincisi, yeşile boyama faaliyetlerinin, yeşil marka imajını baltalaması. İkincisi, yeşile boyama faaliyetlerinin, tüketicilerinin yeşil marka sadakatine zarar vermesi. Üçüncüsü ise, yeşile boyamanın, tüketicilerinin yeşil satın alma davranışını ortadan kaldırması. Bu bakımdan işletmelerin çevreci olma iddiasını güçlendirmesi ve yeşile boyama faaliyetlerini sınırlandırması önemli gözükmektedir.

Araştırma kapsamında yeşil marka imajının ve yeşil marka sadakatinin yeşil satın alma davranışını pozitif etkilediği tespit edilmiştir $\left(\mathrm{H}_{4}\right.$ ve $\left.\mathrm{H}_{5}\right)$. Elde edilen sonuçlar literatürde gerçekleştirilen çalışmalarla (Chen, 2008; Dowling, 1986; Chen, 2010; Flavian vd., 2005; Tariq vd., 2013; Wang ve Tsai, 2014; Shah vd., 2012; Souiden ve Pons, 2009; Tariq vd., 2013; Chi vd., 2009; Kalafatis vd., 1999; Balmer vd., 2009) paralellik göstermektedir. Chen (2010) gerçekleştirmiş olduğu çalışmasında işletmelerin yeşil marka imajlarını arttırmasının müşterilerin yeşil satın alma davranışına olumlu yönde yansıyacağını ifade etmiştir. Chen ayrıca sürdürülebilir kalkınmaya yönelik tüketici sadakatinin, çevresel sürdürülebilirlik açısından tüketici satın alma davranışını olumlu yönde etkileyeceğini tespit etmiştir. Flavian vd. (2005) marka imajının, algılanan riski azaltarak tüketici satın alma davranışı üzerinde olumlu bir etkisi olduğunu belirlemişlerdir. Souiden ve Pons (2009) ve Tariq vd. (2013) gerçekleştirmiş oldukları çalışmalarında, müşteri sadakatinin satın alma davranışıyla olumlu bir şekilde ilişkili olduğunu tespit etmişlerdir. İşletmeler, yeşile boyama faaliyetlerini ortadan kaldırarak, müşterilerinin yeşil satın alma davranışını artırmak için yeşil marka imajını ve yeşil marka sadakatini geliştirmek adına bütün fırsatları değerlendirmelidir. İşletmeler sınırlı kaynaklara sahip olduklarından, yeşil satın alma davranışının olumsuz belirleyicisi olan yeşile boyamayı ortadan kaldırarak iki olumlu belirleyici olan yeşil marka imajı ve yeşil marka sadakati geliştirmek için kaynaklarını daha etkin bir şekilde kullanmalıdırlar.

Çalışmada ayrıca yeşile boyama faaliyetleri ile yeşil marka imajı ve yeşil marka sadakatinin yeşil satın alma davranışı üzerinde nasıl bir aracı etkiye sahip olduğu belirlenmeye çalışılmıştır. Gerçekleştirilen analizler neticesinde yeşile boyama ile yeşil marka imajının ve yeşil marka sadakatinin yeşil satın alma davranışı üzerinde negatif yönde kısmi aracılık (rekabetçi) etkisi tespit edilmiştir. Bu kapsamda $\mathrm{H}_{6}$ ve $\mathrm{H}_{7}$ hipotezleri kabul edilmiştir. Çalışma sonuçları, yeşile boyamanın, yeşil marka imajı ve yeşil marka sadakati yoluyla 


\section{S. Çavuşoğlu 13/3 (2021) 2146-2161}

tüketicilerinin yeşil satın alma davranışını olumsuz yönde etkilemek için iki dolaylı yolu olduğunu doğrulamıştır. Literatürde her iki değişkenin aracılık ettiği sınırlı sayıda çalışma mevcuttur. Gerçekleştirilen çalışmaya paralel olarak Chen vd. (2020)'nin çalışması benzerlik göstermektedir. Chen vd., yeşil ürünler satın alma deneyimi olan Tayvanlı tüketiciler üzerinden gerçekleştirmiş oldukları çalışmalarında, yeşil marka imajı ve yeşil marka sadakatinin yeşile boyama ve yeşil satın alma davranışı arasında kısmen aracılık ettiğini tespit etmişlerdir. Pazardaki yeşil ürünlere olan güçlü ihtiyaç dünyayı değiştirmekte, bu nedenle işletmeler rekabet edebilmek için yeşil pazarlamayı benimsemeye isteklidirler. Literatür, yeşil ürünlerin çevresel iddialarının doğru ve şeffaf olması gerektiğini savunsa da, yeşile boyama pazarda hala etkin bir şekilde kullanılmaktadır (Chen ve Chang, 2013a). İşletmelerin yeşile boyama faaliyetlerini azaltarak, yeşil marka imajı ve yeşil marka sadakati aracılığıyla tüketicilerinin yeşil satın alma davranışını artırmak için kritik bir yaklaşım göstermesinin önemli olduğu söylenebilir.

\subsection{Teorik ve Pratik Çıkarmmlar}

Bu araştırma genel olarak farklı teorik katkılar sunmaktadır. İlk olarak, çalışma, yeşile boyamanın yeşil marka imajı ve yeşil marka sadakati üzerindeki etkilerini tartışmaktadır ve bu durumunda yeşil satın alma davranışını daha da etkileyeceğini dile getirmektedir. Bu nedenle çalışma, yeşil pazarlama araştırmasını genişletmek adına yeşile boyamanın azaltılması, yeşil marka imajının ve yeşil marka sadakatinin arttırılmasını önermektedir. Ayrıca çalışma yeşil satın alma davranışını geliştirmek için marka imajı ve marka sadakati kavramlarını birleştirmektedir. İkinci olarak, önceki araştırmalar yeşile boyamanın marka imajı üzerindeki olumsuz etkisini tespit etmiş olsa da (Polonsky vd., 2010), yeşile boyamanın ve yeşil satın alma davranışı arasındaki ilişkiyi araştıran sınırlı sayıda çalışmanın olduğu görülmektedir. Çalışma, yeşile boyamanın yeşil satın alma davranışını olumsuz etkilediğini kanıtlamaktadır. Bu bakımdan gerçekleştirilen çalışma alanyazındaki araştırma boşluğunu doldurmaktadır. Üçüncü olarak araştırma, yeşile boyama ve yeşil satın alma davranışı arasındaki olumsuz ilişkinin kısmen yeşil marka imajı ve yeşil marka sadakati aracılı̆̆ıla gerçekleştiğini doğrulamaktadır. Çalışmada elde edilen sonuçlar doğrultusunda yeşil marka imajının ve yeşil marka sadakatinin araştırma çerçevesinde iki aracı olduğunu kanıtlamaktadır. Son olarak, yeşile boyama faaliyetlerinin azalması bunun akabinde yeşil marka imajının ve yeşil marka sadakatinin artması, müşterilerin yeşil satın alma davranışını geliştirmelerine yardımcı olabileceği düşünülmektedir.

Bu araştırma, marka imajı, marka sadakati ve satın alma davranışı araştırmalarını yeşil pazarlama alanına uygulamaktadır. Ayrıca çalışma yeşile boyama literatürünü genişletmektedir. Bu araştırmanın dört pratik katkısı olduğu düşünülmektedir. İlk olarak, çalışma, işletmelerin yeşile boyama faaliyetlerini azaltılmasının yalnızca yeşil marka imajını ve yeşil marka sadakatini yükseltmekle kalmayıp, aynı zamanda müşterilerinin çevreci satın alma davranışını da geliştirebileceğini göstermektedir. İşletmeler, müşterilerinin yeşil satın alma davranışını iyileştirmeye istekliyse, yeşile boyama konusundaki şüphelerini azaltmalı ve yeşil marka imajını ve yeşil marka sadakatini geliştirmelidir. İkinci olarak, işletmelerin yeşil marka imajlarını artırmaları gerekmektedir. Yeşil marka imajı, araştırma çerçevesinde kısmi bir aracılık rolü oynadığından, işletmeler, yeşil satın alma davranışını iyileştirmek için yeşil marka imajını geliştirebilir. Üçüncü olarak, yeşil marka sadakati, araştırma çerçevesinde kısmi bir aracılık etkisine sahiptir. Bu bakımdan işletmeler tüketicilerinin yeşil satın alma davranışını artırmak için yeşil marka sadakatini iyileştirmesi gerekmektedir. Son olarak, bu araştırma, yeşile boyamanın, yeşil marka imajı ve yeşil satın alma davranışıyla olumlu bir şekilde ilişkili olan yeşil marka sadakati ile negatif ilişkili olduğunu göstermektedir. Yeşile boyama yalnızca tüketicilerin yeşil satın alma davranışın doğrudan olumsuz etkilemekle kalmayıp, aynı zamanda yeşil marka imajı ve dolaylı olarak tüketicilerinin yeşil marka bağlllığı yoluyla da olumsuz yönde etkileyebilmektedir. Pazarda yeşile boyama faaliyetleri azalırsa, tüketiciler, yeşil pazarlamanın daha etkili hale gelmesi için yeşil iddialara güvenmeye istekli olacaktır. Yeşile boyamayı azaltmak için işletmeler, yeşil iddialarını daha güvenilir ve şeffaf hale getirmek zorundadır. Ek olarak, işletmeler yeşile boyama kaynaklarını ortadan kaldırmalıdır. İşletmelerin yeşile boyama kaynaklarını ortadan kaldırması, yeşil marka imajını ve yeşil marka sadakatini artırmasına ve bunun akabinde tüketicilerin yeşil satın alma davranışını daha da geliştirmesini sağlayabilir.

\subsection{Sınırlılıklar ve Gelecek Çalışmalar için Öneriler}

Çalışmanın evrenini yeşil ürünler satın alma deneyimi olan bireyler oluşturmaktadır. Gelecekteki araştırmalar normal ürünlerin satın alma deneyimlerine odaklanabilir ve bu çalışma ile karşılaştırılabilir. Bu araştırma Türkiye'de uygulanmıştır; gelecekteki araştırmalarda diğer ülkelere odaklanabilir ve bu çalışma ile 
karşılaştırmalı bir şekilde analize tabi tutulabilir. Araştırma modelini test etmek için yalnızca anket tekniği kullanılmıştır. Gelecekteki araştırmalar diğer metodolojileri uygulayabilir. Çalışmanın sonuçları araştırmacılar, uygulayıcılar, yöneticiler ve politika yapıcılar için yararlı olacağı ve referans olarak gelecekteki araştırmalara katkılar sağlayacağı düşünülmektedir.

\section{Kaynakça}

Balmer, J. M., Powell, S. M., Elving, W., Pomering, A. and Johnson, L. W. (2009). Explicating corporate identity. Corporate Communications: An International Journal, 14(4), 420-439.

Chang, C. H. (2011). The influence of corporate environmental ethics on competitive advantage: The mediation role of green innovation. Journal of Business Ethics, 104(3), 361-370.

Chang, N. J. and Fong, C. M. (2010). Green product quality, green corporate image, green customer satisfaction, and green customer loyalty. African Journal of Business Management, 4(13), 28-36.

Chen, Y. S. (2007). The positive effect of green intellectual capital on competitive advantages of firms. Journal of Business Ethics, 77(3), 271-286.

Chen, Y. S. (2008). The driver of green innovation and green image-green core competence. Journal of Business Ethics, 81(3), 531-543.

Chen, Y. S. (2010). The drivers of green brand equity: Green brand image, green satisfaction, and green trust. Journal of Business Ethics, 93(2), 307-319.

Chen, Y. S. (2013). Towards green loyalty: Driving from green perceived value, green satisfaction, and green trust. Sustainable Development, 21(5), 294-308.

Chen, Y. S. and Chang, C.-H. (2012). Enhance green purchase intentions. Management Decision, 50(3), 502-520.

Chen, Y. S. and Chang, C.-H. (2013a). Enhance environmental commitments and green intangible assets toward green competitive advantages: An analysis of structural equation modeling (SEM). Quality $\mathcal{E}$ Quantity, 47(1), 529-543.

Chen, Y. S. and Chang, C.-H. (2013b). Greenwash and green trust: The mediation effects of green consumer confusion and green perceived risk. Journal of Business Ethics, 114(3), 489-500.

Chen, Y. S. and Chang, C.-H. (2013c). Towards green trust. Management Decision, 51(1), 63-82.

Chen, Y. S. and Chang, C.-H. (2013d). Utilize structural equation modeling (SEM) to explore the influence of corporate environmental ethics: The mediation effect of green human capital. Quality $\mathcal{E}$ Quantity, 47(1), 79-95.

Chen, Y. S., Chang, C. H., Lin, C.-Y. and Lai, P.-Y. (2015). The negative impact of greenwash on green purchase intention. 21st ISERD International Conference, Shanghai, China, December 7.

Chen, Y. S., Huang, A. F., Wang, T. Y. and Chen, Y. R. (2020). Greenwash and green purchase behaviour: the mediation of green brand image and green brand loyalty. Total Quality Management $\mathcal{E}$ Business Excellence, 31(1-2), 194-209.

Chen, Y. S., Lai, S.-B. and Wen, C.-T. (2006). The influence of green innovation performance on corporate advantage in Taiwan. Journal of Business Ethics, 67(4), 331-339.

Chi, H. K., Yeh, H. R. and Yang, Y. (2009). The impact of brand awareness on consumer purchase intention: The mediating effect of perceived quality and brand loyalty. Journal of International Management Studies, 4(1), 135-144.

Cho, G., Hwang, H., Sarstedt, M. and Ringle, C. M. (2020). Cutoff criteria for overall model fit indexes in generalized structured component analysis. Journal of Marketing Analytics, 8(4), 189-202.

Cohen, J. (1988). Statistical power analysis for the behavioral sciences. (2nd Ed.). Hillsdale, NJ: Lawrence Erlbaum Associates, Publishers.

Cretu, A. E. and Brodie, R. J. (2007). The influence of brand image and company reputation where manufacturers market to small firms: A customer value perspective. Industrial Marketing Management, 36(2), 230-240. 
Çavuşoğlu, S., Demirağ, B., Jusuf, E. and Gunardi, A. (2020). The Effect of Attitudes Toward Green Behaviors on Green Image, Green Customer Satisfaction and Green Customer Loyalty. GeoJournal of Tourism and Geosites, 33(4spl), 1513-1519.

Dağ, K. ve Durmaz, Y. (2020). Marka Özgünlüğünün Marka İmajı ve Marka Tercihindeki İlişkisinde Marka Güveninin Aracılık Rolü. OPUS Uluslararası Toplum Araştırmaları Dergisi, 16(32), 4840-4874.

Davari, A. and Rezazadeh, A. (2013). Structural equation modeling with PLS. Tehran: Jahad University, 215(2), 224.

Demirağ, B. ve Durmaz, Y. (2019). Algılanan Hizmet Kalitesinin Algılanan Değer ve Tutumsal Marka Sadakati Üzerindeki Etkisinin İncelenmesi: 5 Yıldızlı Sayfiye ve Şehir Otelleri Örneği. OPUS Uluslararası Toplum Araştırmaları Dergisi, 11(18), 693-726.

Demirağ, B. ve Durmaz, Y. (2020). Marka Yönetimi. (1 Basım). İstanbul: Hiper Yayın.

Dennis, C., King, T. and Martenson, R. (2007). Corporate brand image, satisfaction and store loyalty: A study of the store as a brand, store brands and manufacturer brands. International Journal of Retail $\mathcal{E}$ Distribution Management, 35(7), 544-555.

Diamantopoulos, A. and Siguaw, J. A. (2006). Formative versus reflective indicators in organizational measure development: A comparison and empirical illustration. British journal of management, 17(4), 263-282.

Dick, A. S. and Basu, K. (1994). Customer loyalty: Toward an integrated conceptual framework. Journal of the Academy of Marketing Science, 22(2), 99-113.

Dowling, G. R. (1986). Managing your corporate images. Industrial Marketing Management, 15(2), 109-115.

Durmaz, Y. ve Dağ, K. (2018). Marka Özgünlüğünün Marka Sadakati Üzerindeki Etkileri: Cep Telefonu Markaları Üzerine Bir Araştırma. Akademik Araştırmalar ve Çalı̧̧malar Dergisi (AKAD), 10(19), 489501.

Flavian, C., Guinaliu, M. and Torres, E. (2005). The influence of corporate image on consumer trust. Internet Research, 15(4), 447-470.

Fornell, C. and Larcker, D. F. (1981). Evaluating structural equation models with unobservable variables and measurement error. Journal of Marketing Research, 18(1), 39-50.

Gefen, D., Straub, D. and Boudreau, M. C. (2000). Structural equation modeling and regression: Guidelines for research practice. Communications of the association for information systems, 4(1), 1-79.

Ghozali, I. and Latan, H. (2015). Partial least squares konsep, teknik dan aplikasi menggunakan program smartpls 3.0 untuk penelitian empiris. Semarang: Badan Penerbit UNDIP.

Gillespie, E. (2008). Stemming the tide of 'greenwash'. Consumer Policy Review, 18(3), 79-83.

Gold, A. H., Malhotra, A. and Segars, A. H. (2001). Knowledge management: An organizational capabilities perspective. Journal of management information systems, 18(1), 185-214.

Hair, J. F., Sarstedt, M., Matthews, L. M. and Ringle, C. M. (2016). Identifying and treating unobserved heterogeneity with FIMIX-PLS: Part I-method. European Business Review, 28(1), 63-76.

Hair, J. F., Ringle, C. M. and Sarstedt, M. (2011). PLS-SEM: Indeed a silver bullet. Journal of Marketing Theory and Practice, 19(2), 139-152.

Hair, J. F., Risher, J. J., Sarstedt, M. and Ringle, C. M. (2019). When to use and how to report the results of PLSSEM. European Business Review, 31(1), 2-24.

Hamann, R. and Kapelus, P. (2004). Corporate social responsibility in mining in southern Africa: Fair accountability or just greenwash?. Development, 47(3), 85-92.

Henseler, J., Hubona, G. and Ray, P. A. (2016). Using PLS path modeling in new technology research: updated guidelines. Industrial Management \& Data Systems, 116(1), 2-20.

Hoedeman, O. (2002). Rio +10 and the greenwash of corporate globalization. Development, 45(3), 39-42.

Horiuchi, R., Schuchard, R., Shea, L. and Townsend, S. (2009). Understanding and preventing greenwash: A business guide. London: Futerra Sustainability Communications.

Kaiser, H. F. (1974). An index of factorial simplicity. Psychometrika, 39(1), 31-36. 
Kalafatis, S. P., Pollard, M., East, R. and Tsogas, M. H. (1999). Green marketing and Ajzen's theory of planned behaviour: A cross-market examination. Journal of Consumer Marketing, 16(5), 441-460.

Kement, Ü. (2019). Yeşil Tutumunun Davranışsal Niyet Türlerine Etkisi: Yeşil İmajın Aracılık Rolü. OPUS Uluslararası Toplum Araştırmaları Dergisi, 10(17), 370-394.

Kement, Ü. ve Bükey, A. (2020). Yeşil satın alma davranış teorisi kapsamında ekorekreasyon faaliyetlerine katılan bireylerin davranışlarının incelenmesi: Bolu Yedigöller örneği. Tourism and Recreation, 2(2), 134-145.

Kement, Ü. ve Güçer, E. (2018). Consumers' Environmentally Friendly Recreational Behaviours in Recreational Activities: Camping Sample. İşletme Araştırmaları Dergisi, 10(4), 772-793.

Kim, Y. and Choi, S. M. (2005). Antecedents of green purchase behavior: An examination of collectivism, environmental concern, and PCE. Advances in Consumer Research, 32, 592-599.

Kline, R. B. (2011). Principles and practice of structural equation modeling. New York, NY: Guilford.

Laufer, W. S. (2003). Social accountability and corporate greenwashing. Journal of Business Ethics, 43(3), 253261.

Lyon, T. P. and Maxwell, J. W. (2011). Greenwash: Corporate environmental disclosure under threat of audit. Journal of Economics \& Management Strategy, 20(1), 3-41.

Malhotra, N. K. (2004). Marketing Research an Applied Orientation (4. Edition). Pearson Prentice Hall, New Jersey.

Mudambi, S. M., Doyle, P. and Wong, V. (1997). An exploration of branding in industrial markets. Industrial Marketing Management, 26(5), 433-446.

Nitzl, C. and Hirsch, B. (2016). The drivers of a superior's trust formation in his subordinate. Journal of Accounting \& Organizational Change, 12(4), 472-503.

Nunnally, J. and Bernstein, I. (1994). Psychometric Theory, 3rd edn, 1994. McGraw-Hill, New York.

O'brien, R. M. (2007). A caution regarding rules of thumb for variance inflation factors. Quality \& quantity, 41(5), 673-690.

Oliver, R. L. (1999). Whence consumer loyalty?. Journal of Marketing, 63, 33-44.

Padgett, D., and Allen, D. (1997). Communicating experiences: A narrative approach to creating service brand image. Journal of Advertising, 26(4), 49-62.

Parguel, B., Benoît-Moreau, F. and Larceneux, F. (2011). How sustainability ratings might deter'greenwashing': A closer look at ethical corporate communication. Journal of Business Ethics, 102(1), 15-28.

Park, C. W., Jaworski, B. J. and Maclnnis, D. J. (1986). Strategic brand concept-image management. Journal of Marketing, 50(4), 135-145.

Polonsky, M. J., Grau, S. L. and Garma, R. (2010). The new greenwash? Potential marketing problems with carbon offsets. International Journal of Business Studies, 18(1), 49-54.

Pomering, A. and Johnson, L. W. (2009). Advertising corporate social responsibility initiatives to communicate corporate image: Inhibiting scepticism to enhance persuasion. Corporate Communications: An International Journal, 14(4), 420-439.

Porter, M. E. and Van der Linde, C. (1995). Toward a new conception of the environment-competitiveness relationship. Journal of Economic Perspectives, 9(4), 97-118.

Ramus, C. A. and Montiel, I. (2005). When are corporate environmental policies a form of greenwashing?. Business \& Society, 44(4), 377-414.

Self, R. M., Self, D. R. and Bell-Haynes, J. (2010). Marketing tourism in the Galapagos Islands: Ecotourism or greenwashing?. International Business \& Economics Research Journal (IBER), 9(6), 111-126.

Shah, S. S. H., Aziz, J., Jaffari, A., Waris, S., Ejaz, W., Fatima, M. and Sherazi, S. K. (2012). The impact of brands on consumer purchase intentions. Asian Journal of Business Management, 4(2), 105-110.

Slaughter, P. (2008). Avoid the pitfalls of greenwash. Home Furnishings Business, 3(2), 32-36. 


\section{S. Çavuşoğlu 13/3 (2021) 2146-2161}

Smith, R.A., White-McNeil, A. and Ali, F. (2020). Students' perceptions and behavior toward on-campus foodservice operations. International Hospitality Review, 34(1), 13-28.

Souiden, N. and Pons, F. (2009). Product recall crisis management: The impact on manufacturer's image, consumer loyalty and purchase intention. Journal of Product \& Brand Management, 18(2), 106-114.

Sönmez Çakır, F. (2020). Kısmi En Küçük Kareler Yapısal Eşitlik Modellemesi (PLS-SEM) SmartPLS 3.2. Uygulamaları. Gazi Kitabevi, Ankara.

Tariq, M. I., Nawaz, M. R., Nawaz, M. M. and Butt, H. A. (2013). Customer perceptions about branding and purchase intention: A study of FMCG in an emerging market. Journal of Basic and Applied Scientific Research, 3(2), 340-347.

Ural, A. ve Kılıç, I. (2006). Bilimsel Araştırma Süreci ve SPSS ile Veri Analizi. Detay Yayıncılık, Ankara.

Vinzi, V. E., Trinchera, L. and Amato, S. (2010). PLS path modeling: from foundations to recent developments and open issues for model assessment and improvement. In Handbook of partial least squares (pp. 4782). Springer, Berlin, Heidelberg.

Wang, Y.-H. and Tsai, C.-F. (2014). The relationship between brand image and purchase intention: Evidence from award winning mutual funds. The International Journal of Business and Finance Research, 8(2), 2740.

Wu, P. C., Yeh, G. Y.-Y. and Hsiao, C.-R. (2011). The effect of store image and service quality on brand image and purchase intention for private label brands. Australasian Marketing Journal (AMJ), 19(1), 30-39.

Yaseen, N., Tahira, M., Gulzar, A. and Anwar, A. (2011). Impact of brand awareness, perceived quality and customer loyalty on brand profitability and purchase intention: A resellers' view. Interdisciplinary Journal of Contemporary Research in Business, 3(8), 833-837.

Zhao, X., Lynch Jr, J. G. and Chen, Q. (2010). Reconsidering Baron and Kenny: Myths and truths about mediation analysis. Journal of consumer research, 37(2), 197-206. 